\title{
PENGARUH KUALITAS PRODUK DAN NILAI PELANGGAN TERHADAP LOYALITAS PELANGGAN ES MAHKOTA DI KOTA PALU (Studi Pada Pelanggan Es Mahkota)
}

\author{
AAN MAULANA \\ ROSIDA P. ADAM \\ BENYAMIN PARUBAK \\ Program Studi Manajemen, Fakultas Ekonomi, Universitas Tadulako \\ Email: aanmaulana1611@gmail.com
}

\begin{abstract}
This research intends to identify and to analyze the effect of product quality and customer value of customer of Es Mahkota in Palu City, the effectof product quality of customer of Es Mahkota in Palu City. This quantitave research show relation between variables. Population of this research is the customer of Es Mahkota in Palu City that has consumed the product for three to four times. 90 samples as respondent was taken through purposive sample. Data were collected using questionnarie and analyzed through multiple linear regression using the application of SPSS release 20. The result of this research revealed that product quality and customer value affects the loyality of cuetomer of Es Mahkota in Palu City, product quality affects the loyality of customer of Es Mahkota in palu City, and customer value affects the loyality of customer of Es Mahkota in Palu City.
\end{abstract}

Keywords: Product Quality, Customer Value, Loyality of Customer.

\begin{abstract}
ABSTRAK
Tujuan penelitian ingin mengetahui dan menganalisa: (1) pengaruh kualitas produk dan nilai pelanggan terhadap loyalitas pelanggan Es Mahkota di Kota Palu, (2) pengaruh kualitas produk terhdap loyalitas pelanggan Es Mahkota di Kota Palu, dan (3) pengaruh nilai pelanggan terhadap loyalitas pelanggan Es Mahkota di Kota Palu. Jenis penelitian yang digunakan adalah kuantitatif (menunjukan hubungan antar variabel). Populasi dalam penelitian adalah konsumen atau pembeli Es Mahkota di Kota palu yang telah mengkonsumsi produk sebanyak 3-4 kali. Teknik penarikan sampel dalam penelitian ini menggunakan purposive sampling, dengan jumlah sampel sebanyak 90 responden. Pengambilan data menggunakan kuesioner. Metode analisis yang digunakan analisis regresi linear berganda dengan menggunakan aplikasi SPSS release 20. Hasil penelitian menunjukan bahwa (1) terdapat pengaruh kualitas produk dan nilai pelanggan terhdap loyalitas pelanggan Es Mahkota di Kota Palu, (2) terdapat pengaruh kualitas produk terhadap loyalitas pelanggan Es Mahkota di Kota Palu, (3) terdapat pengaruh nilai pelanggan terhadap loyalitas pelanggan Es Mahkota di Kota Palu.
\end{abstract}

Kata Kunci: Kualitas Produk, Nilai Pelanggan Loyalitas Pelanggan.

\section{PENDAHULUAN}

Es Teler Mahkota merupakan minuman dengan tampilan yang menarik dan kombinasi campuran buah yang segar menjadikan Es Mahkota salah satu minuman penyegar sekaligus penyehat tubuh yang dikarenakan rasa yang khas dan buah-buah yang digunakan adalah buah yang segar dan sangat cocok untuk dikonsumsi oleh siapa saja. Es Teler Mahkota merupakan salah satu tempat yang populer dikalangan banyak masyarakat terutama pada kalangan remaja dan anak muda.

Kualitas produk yang menjadi faktor penting yang berpengaruh dalam penciptaan loyalitas pelanggan. Kualitas produk berperan penting untuk dapat menentukan kepuasan konsumen setelah 
Maulana, A.

melakukan pembelian atau pemakaian terhadap suatu produk, dengan meningkatkan kualitas produk untuk memenuhi kebutuhan dari konsumen merupakan tujuan utama bagi setiap perusahaan. Pelanggan akan merasa puas ketika mendapatkan sesuatu yang diharapkan dari suatu kinerja dan produk yang digunakannya.

Alida Palilati (2007) nilai pelanggan merupakan persepsi pelanggan terhadap nilai atas kualitas yang ditawarkan relatif lebih tinggi dari pesaing akan mempengaruhi tingkat loyalitas pelanggan, semakin tinggi persepsi nilai yang dirasakan oleh pelanggan, maka semakin besar kemungkinan terjadinya hubungan atau transaksi. Nilai bagi pelanggan bisa dapat dikatakan sebagai cerminan dari kualitas, manfaat dan pengorbanan yang diberikan untuk mendapatkan sebuah produk.

\section{KAJIAN LITERATUR}

\section{Pengertian Kualitas Produk}

Menurut Kotler \& keller (2008:272) kualitas produk adalah salah satu sarana positioning utama pasar. Kualitas memiliki dampak langsung pada kinerja produk atau jasa. Menurut Kotler \& Keller (2009:143) kualitas produk adalah totalitas fitur dan karakteristik produk atau jasa yang bergantung pada kemampuanya untuk memuaskan kebutuhan yang dinyatakan atau tersirat.

\section{Dimensi Kualitas Produk}

Mengavaluasi loyalitas terhadap produk, jasa, atau perusahaan tertentu, konsumen umumnya mengacu pada berbagai faktor atau dimensi yang menjadi suatu tolak ukur untuk mengetahui tingkat loyalitas pelanggan. Berikut ini 5 dimensi Kualitas Produk yang diungkapkan oleh Tjiptono (2008:25) sebagai berikut:

1. Kinerja (Performance), yaitu karakteristik operasi pokok dari produk inti.

2. Kesesuaian dengan spesifikasi (Conformance to Specification), yaitu sejauh mana karakteristik desain dan operasi memenuhi standar-standar yang telah ditetapkan sebelumnya.

3. Daya tahan (durability), yaitu berkaitan dengan berapa lama produk tersebut dapat terus digunakan.

4. Estetika, yaitu daya tarik produk terhadap panca indera.

5. Kualitas yang dipersepsikan (Preceived Quality) merupakan persepsi konsumen terhadap keseluruhan kualitas atau keunggulan suatu produk.

\section{Pengertian Nilai Pelanggan}

Menurut Tjiptono (2006:10) menjelaskan bahwa nilai pelanggan ditentukan oleh selisih antara manfaat total dan biaya total bagi pelanggan, sedangkan menurut Wahyuningsih (2009:63) nilai pelanggan mempunyai beberapa kompenen di antaranya adalah kualitas barang dan jasa, harga, performa, persepsi, hubungan dengan pelanggan, dan sebagainya.

\section{Dimensi Nilai Pelanggan}

Menurut (Tjiptono, 2005:295), dimensi nilai pelanggan terdiri dari 3 yaitu:

1. Emotional value, utilitas yang berasal dari perasaan atau emosi positif yang ditimbulkan secara tiba-tiba atau spontan dari pelanggan.

2. Social value, utilitas yang didapat dari kemamapuan produk untuk meningkatkan konsep diri sosial konsumen.

3. Fungcional value, utilitas yang didapatkan dari produk karena reduksi biaya jangka pendek dan jangka panjang.

\section{Pengertian Loyalitas}

Tjiptono (2004:110) loyalitas konsumen adalah komitmen pelanggan terhadap suatu merek, toko atau pemasok berdasarkan sifat yang sangat positif dalam pembelian jangka panjang, dan menurut Tjiptono (2011:481) loyalitas adalah perilaku pembelian ulang semata-mata menyangkut pembelian 
merek tertentu yang sama secara berkala (bisa dikarenakan memang hanya satu-satunya merek yang tersedia, merek termurah dan sebagainya, sedangkan menurut Oliver dalam Ratih (2005:128) loyalitas pelanggan adalah komitmen pelanggan bertahan secara mendalam untuk berlanggan kembali untuk berlanggan kembali atau melakukan pembelian ulang produk/jasa terpilih secara konsisten dimasa yang akan datang, meskipun pengaruh situasi dan usaha-usaha pemasaran mempunyai potensi untuk perubahan perilaku.

\section{Kerangka Pemikiran}

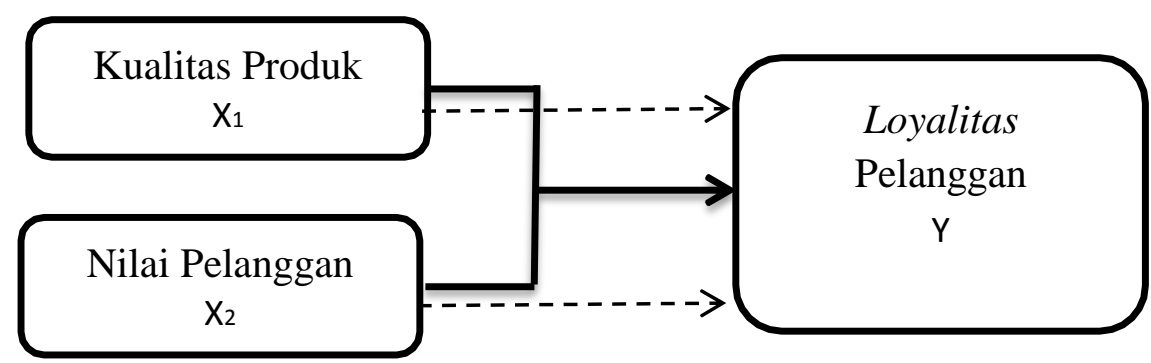

Gambar 1

Kerangka Pemikiran

Teori dari kerangka berpikir di atas dapat disusun beberapa hipotesis sebagai berikut:

1. Variabel kualitas produk dan nilai pelanggan secara simultan berpengaruh terhadap loyalitas pelanggan.

2. Variabel kualitas produk berpengaruh terhadap loyalitas pelanggan.

3. Variabel nilai pelanggan berpengaruh terhadap loyalitas pelanggan.

\section{METODE PENELITIAN}

Penelitian ini digunakan untuk memperoleh gambaran tentang pengaruh kualitas produk dan nilai pelanggan terhadap loyalitas pelanggan pada warung Es Teler Mahkota di Kota palu. Sehubungan dengan hal tersebut maka penelitian ini menggunakan tipe deskriptif kausal yang dilakukan melalui pengumpulan data di lapangan pada Warung Es Teler Mahkota Kota Palu. Menurut Mudrajad (2009:148) penelitian deskriptif meliputi pengumpulan data untuk diuji hipotesis atau menjawab (pertanyaan mengenai status terakhir dari subjek penelitian. Teknik pengumpulan data yang dilakukan dengan cara observasi, kuesioner dan dokumentasi. Populasi dalam penelitian ini adalah pelanggan Es Teler Mahkota di Kota Palu. Teknik pengambilan sampel untuk menentukan sampel yang akan digunakan dalam penelitian ini menggunakan purposive sampling. Mengingat jumlah popuasi tidak diketahhui secara pasti, ukuran sampel dalam penelitian dilakukan dengan menggunakan pendekatan yang dirujuk dari Sugiyono (2012) yang menyatakan bahwa untuk menentukan sampel dari populasi yang tidak diketahui adalah minimal 10 kali dari jumlah variabel yang diteliti (variabel independen dan dependen). Variabel dalam penelitian ini adalah 3 yang terdiri dari variabel indepen dan dependen. Berdasarkan pertimbangan tersebut maka jumlah sampel sebesar 30 × 3 variabel yaitu 90 responden dengan demikian sampel dari penelitian ini sebanyak 90 responden.

\section{Alat Analisis}

Metode analisis yang digunakan dalam penelitian ini adalah dengan pendekatan statistik deskriptif melalui penggunaan alat analisis statistik regresi linear berganda untuk mengetahui kekuatan pengaruh variabel $\mathrm{X}$ terhadap variabel $\mathrm{Y}$, dalam penelitian ini menggunakan bantuan komputer program SPSS Release 20.0. 
Maulana, A.

\section{HASIL DAN PEMBAHASAN}

Tabel 1

Hasil Uji Analisis Regresi Linear Berganda

\begin{tabular}{|c|c|c|c|c|c|}
\hline \multicolumn{6}{|c|}{ Dependen Variabel Y = Loyalitas Pelanggan } \\
\hline \multirow[t]{2}{*}{ Variabel Independen } & \multicolumn{2}{|c|}{$\begin{array}{c}\text { Unstandardized } \\
\text { Coefficients }\end{array}$} & \multirow{2}{*}{$\begin{array}{r}\text { Standardized } \\
\text { Coefficients }\end{array}$} & \multirow[t]{2}{*}{$\mathrm{T}$} & \multirow[t]{2}{*}{ Sig } \\
\hline & $\mathbf{B}$ & Std. Error & & & \\
\hline (Constant) & 0,928 & 228 & & 4,072 & 000 \\
\hline $\begin{array}{c}\mathrm{X} 1 \\
\text { ( Kualitas Produk) }\end{array}$ & , 464 & 058 & ,495 & 7,945 & ,000 \\
\hline $\begin{array}{c}\mathrm{X} 2 \\
\text { (Nilai Pelanggan) }\end{array}$ & ,388 & ,046 &, 525 & 8,438 & 000 \\
\hline Multiple R & & & $=0,839^{\mathrm{a}}$ & & \\
\hline Sig. F & & & $=0,000$ & & \\
\hline Adjusted R Square & & & $=0,698$ & & \\
\hline
\end{tabular}

Berdasarkan penjabaran di atas menunjukkan bahwa, variabel independen yang dianalisis yaitu variabel $\left(\mathrm{X}_{1}\right.$ dan $\mathrm{X}_{2}$ ) memberikan pengaruh posotif terhadap variabel dependen (Y), yaitu Loyalitas Pelanggan Es Mahkota Kota Palu, agar lebih jelasnya penjelasan bentuk persamaan tersebut dapat dilihat berikut ini:

1. Nilai Konstanta sebesar 0,928, artinya jika variabel (Kualitas Produk dan Nilai Pelanggan) bernilai 0 atau konstan, maka variabel dependen (Loyalitas Pelanggan Es Mahkota Kota Palu) nilainya sebesar 0,928 . setiap ada kenaikan pada variabel independen sebesar satu satuan maka akan meningkatkan variabel dependen sebesar nilai koefisiensi beta masing-masing variabel independen yang dikalikan dengan besarnya kenaikan yang terjadi.

2. Koefisien regresi kualitas produk $\left(\mathrm{X}_{1}\right)$ sebesar 0,464 , artinya jika ada perubahan terhadap kualitas produk ke arah yang positif atau yang lebih baik, tertutama warung Es Mahkota memperhatikan pada indikator Menggunakan beragam jenis buah yang segar, kualitas rasa, bahan baku, kombinasi rasa, pelayanan hingga kesesuain rasa yang dimiliki Es Mahkota sehingga loyalitas pelanggan akan berubah menjadi satu satuan.

3. Koefisien regresi dimensi nilai pelanggan $\left(\mathrm{X}_{2}\right)$ 0,388, artinya jika ada perubahan terhadap nilai pelanggan ke arah yang positif atau yang lebih baik terutama pada indikator-indikator yang ada pada nilai pelangan sehingga loyalitas pelanggan akan berubah menjadi satu satuan.

\section{Pengujian Hipotesis}

Tabel 2

Hasil Uji F (Simultan)

ANOVA

\begin{tabular}{|l|c|c|c|c|c|}
\hline \multicolumn{1}{|c|}{ Model } & $\begin{array}{c}\text { Sum Of } \\
\text { Squares }\end{array}$ & Df & Mean Square & F & Sig. \\
\hline Regression & 3,413 & 2 & 1,707 & 103,764 &, $000^{\mathrm{b}}$ \\
\hline Residual & 1,431 & 87 &, 016 & & \\
\hline Total & 4,844 & 89 & 89 & & \\
\hline
\end{tabular}


Berdasarkan Tabel di atas, diperoleh angka signifikan sebesar 0,000. angka 0,000 $<0,05$ oleh karena itu, hipotesis diterima. Hal ini berarti terdapat pengaruh secara simultan pada variabel kualitas produk dan nilai pelanggan terhadap loyalitas pelanggan Es Mahkota di Kota palu.

\section{Pembahasan}

1. Variabel Kualitas Produk

Berdasarkan rata-rata jawaban responden, diketahui bahwa secara keseluruhan ratarata jawaban responden adalah setuju dengan total mean sebesar 3,81. Temuan ini mengiktisarkan secara umum responden mengakui bahwa kualitas produk yang diberikan Warung Es Mahkota dinilai cukup berkualitas. Namun diantara indikator kualitas produk pada kuesioner X1.5 (tidak mudah basi) mendapatkan penilaian terendah oleh responden, dan temuan ini memberikan masukan kepada pemilik Es Mahkota untuk lebih memperhatikan buah-buahan yang digunakan dan bahan baku lainnya agar lebih menambah masa waktu Es Mahkota untuk dapat dikonsumsi diwaktu yang berbeda setelah membeli atau pemilik Es Mahkota dapat menyarankan pada pelanggan agar Es Mahkota dapat tahan beberapa jam setelah pembelian, diharapkan agar disimpan pada pendingin agar memberikan ketahanan yang cukup lama pada Es Mahkota tersebut. Berdasarkan Tabel 1, hasil pengujian SPSS diperoleh angka signifikan sebesar 0,000. Angka $0,000<0,05$ oleh karena itu, hipotesis diterima. Hal ini berarti terdapat pengaruh variabel kualitas produk terhadap loyalitas pelanggan Es Mahkota Kota Palu.

2. Variabel Nilai Pelanggan

Berdasarkan rata-rata jawaban responden, diketahui bahwa secara keseluruhan ratarata jawaban responden adalah setuju dengan total mean sebesar 3,69. Temuan ini mengiktisarkan bahwa secara umum responden mengakui bahwa produk yang ditawarkan memberikan nilai yang cukup tinggi. Namun diantara indikator nilai pelanggan pada kuesioner X2.4 (memberikan kekuatan komunitas saat berada di Warung Es Mahkota) mendapatkan penilaian terendah oleh responden, dan temuan ini memberikan masukan kepada pemilik Es Mahkota agar membuatkan kartu anggota atau kartu anggota berkelompok untuk menjadikan konsumen sebagai member pada warung Es Mahkota. tujuannya agar meningkatkan rasa komunitas dan ikatan pertemanan saat berada di Warung Es Mahkota dan merupakan salah satu cara untuk dapat mempertahankan pelanggan agar selalu loyal. Berdasarkan Tabel 1, hasil pengujian SPSS diperoleh angka signifikan sebesar 0,000. Angka $0,000<0,05$ oleh karena itu, hipotesis diterima. Hal ini berarti terdapat pengaruh nilai pelanggan terhadap loyalitas pelanggan Es Mahkota Kota Palu.

\section{KESIMPULAN DAN SARAN}

\section{Kesimpulan}

1. Kualitas produk dan nilai pelanggan secara simultan berpengaruh signifikan terhadap loyalitas pelanggan Es Mahkota di Kota Palu.

2. Kualitas produk secara parsial berpengaruh signifikan terhadap loyalitas pelanggan Es Mahkota di Kota Palu.

3. Nilai pelanggan secara parsial berpengaruh signifikan terhadap loyalitas pelanggan Es Mahkota di Kota Palu. 
Maulana, A.

\section{Saran}

1. Kepada pemilik Es Mahkota agar menghilangkan indikator penyebabnyanya cepat basi dalam Es Mahkota agar dapat memberikan ketahanan buah yang digunakan dalam Es Mahkota atau memberikan saran pada pelanggan agar dapat lebih tahan lama Es Mahkota dapat disimpan dalam lemari pendingin dengan tujuan memberikan ketahanan pada Es Mahkota tersebut.

2. Kepada pemilik Es Mahkota agar membuatkan kartu anggota atau kartu anggota berkelompok untuk menjadikan konsumen sebagai member pada warung Es Mahkota. tujuannya agar meningkatkan rasa komunitas dan ikatan pertemanan saat berada di Warung Es Mahkota dan merupakan salah satu cara untuk dapat mempertahankan pelanggan agar selalu loyal.

\section{REFERENSI}

Hurriyati, Ratih. 2005. Bauran Pemasaran dan Loyalitas Konsumen.Bandung: Alfabeta.

Kotler, Philip, \& Keller Kevin Lane. 2008. Manajemen Pemasaran (13 ed.). Jakarta: Erlangga.

Kotler, Philip, \& Keller Kevin Lane. 2009a. Manajemen Pemasaran (13 ed.). Jakarta: Erlangga.

Kuncoro, Mudrajad. 2009. Metode Riset Untuk Bisnis \& Ekonomi. Jakarta: Erlangga.

Palilati, Alida.2007. Pengaruh Nilai Pelanggan, Kepuasaan Terhadap Loyalitas Nasabah Tabungan Perbankan Di Sulawesi Selatan. Jurnal Manajemen Dan Kewirausahaan, 9(1)

Sugiyono. 2012. Metode Penilitian Dan Administrasi. Bandung: Alfabeta.

Tjiptono, Fandy. 2005. Pemasaran Jasa. Malang: Bayumedia.

Tjiptono, Fandy. 2006. Pemasaran Jasa. Malang: Bayumedia.

Tjiptono, Fandy. 2008. Pemasaran Jasa. Jakarta: Bayumedia Publishing.

Tjiptono, Fandy. 2004. Manajemen Jasa. Yogyakarta: Andi.

Tjiptono, Fandy. 2011. Pemasaran Jasa. Malang: Bayumedia.

Wahyuningsih. 2009. Manajemen Pemasaran. Palu: Tadulako University. Press. 